\title{
Penerapan Kolom Adsorpsi Seri dengan Adsorben Sekam Padi pada Penyisihan Logam Seng (Zn) dari Air Tanah
}

\author{
Shinta Indah ${ }^{1 *}$, Denny Helard ${ }^{1}$, Dian Ramadhan ${ }^{1}$ \\ 'Jurusan Teknik Lingkungan, Fakultas Teknik, Universitas Andalas, Padang, Sumatra Barat, Indonesia
}

Corresponding author:

Shinta Indah

shintaindah@eng.unand.ac.id

Received: February 2021

Accepted: March 2021

Published: March 2021

(C) Shinta Indah et al. This is an open-access article distributed under the terms of the Creative Commons Attribution License, which permits unrestricted use, distribution, and reproduction in any medium, provided the original author and source are credited.

\begin{abstract}
To increase the performance of continuous adsorption with rice husks as adsorbent in Zn removal from groundwater, a series of fixed bed column was applied. The experiments were carried out at the acrylic columns having diameter of $7 \mathrm{~cm}$, column height of $19.5 \mathrm{~cm}$, bed height of $13.5 \mathrm{~cm}$ and flow rate of $2 \mathrm{gpm} / \mathrm{ft}^{2}$ ( $310 \mathrm{~mL} /$ minute) for 540 minutes. The number of columns used were 3 columns arranged in series and the rice husk used were in their original size (1-2 mm). The influent concentration of Zn metal was $7.62 \mathrm{mg} / \mathrm{L}$. The results showed that the use of column adsorption in series increased the removal efficiency of $Z n$ by rice husks, from $33.21 \%$ using 1 column to $51.70 \%$ with 3 columns. The adsorption capacity of $\mathrm{Zn}$ obtained when using 3 columns in series was $3.542 \mathrm{mg} / \mathrm{g}$. In addition, the use of adsorption columns in series can also prolong the saturation of the adsorbent, thereby extending its service life. The overall research results demonstrated that column the adsorption in series with rice husk as an adsorbent has the potential to be applied to remove heavy metals from groundwater.
\end{abstract}

Keywords: column adsorption, groundwater, rice husk, zinc

\section{Pendahuluan}

Pencemaran air tanah semakin marak terjadi seiring meningkatnya aktivitas manusia di bidang industri, domestik dan pertanian. Kegiatan ini menghasilkan berbagai jenis bahan pencemar, salah satunya adalah logam. Salah satu jenis logam adalah logam berat esensial yang merupakan logam dalam jumlah tertentu sangat dibutuhkan oleh organisme, tetapi bisa menimbulkan efek racun jika dalam jumlah yang berlebihan, adalah seng (Zn). Selain berasal dari sumber alami, keberadaaan logam Zn umumnya dihasilkan oleh aktivitas manusia seperti kegiatan bengkel, pengecatan mobil, produksi bahan keramik dan pembuatan kontainer dimana limbahnya terakumulasi di permukaan tanah dan dengan adanya hujan, logam ini akan meresap ke dalam tanah ${ }^{[1][2][3] . ~}$
Dari hasil sampling air tanah di Kampung Kalawi Timur, Padang, pada tahun 2019, didapatkan konsentrasi Zn sebesar $3.328 \mathrm{mg} / \mathrm{L}^{[4]}$. Jika dibandingkan dengan baku mutu menurut PERMENKES No. 492 Tahun 2010 tentang Persyaratan Kualitas Air Minum, dimana konsentrasi Zn yang diperbolehkan adalah 3 $\mathrm{mg} / \mathrm{L}$, dapat disimpulkan bahwa konsentrasi Zn dalam air tanah tersebut telah melebihi baku mutu. Dampak logam Zn jika dikonsumsi dalam jumlah yang berlebih dapat mengakibatkan dehidrasi, ketidakseimbangan elektrolit, sakit perut, mual, dan pusing[5].

Salah satu pengolahan yang dapat diterapkan untuk menyisihkan logam terlarut dalam air adalah adsorpsi. Adsorpsi merupakan peristiwa menempelnya suatu substansi pada permukaan adsorben. Teknik adsorpsi dikenal sebagai salah 
satu teknik yang relatif sederhana, mudah dan murah tetapi mempunyai efisiensi penyisihan yang tinggi sehingga cocok diterapkan pada masyarakat ${ }^{[6]}$. Adsorpsi dilakukan dengan mengontakan adsorben dengan adsorbat pada suatu wadah tanpa ada aliran yang masuk dan keluar untuk sistem batch dan mengalirkan adsorbat ke dalam kolom secara terus menerus untuk sistem kontinu. Adsorpsi sistem kontinu diketahui memberikan hasil yang lebih dapat diandalkan, praktis dan ekonomis untuk diterapkan di lapangan karena sifatnya yang dinamis dibanding sistem batch $^{[7][8] \text {. }}$

Dalam pengoperasiannya, kolom adsorpsi dapat digunakan secara tunggal maupun majemuk dengan konfigurasi paralel atau seri. Pada kolom adsorpsi paralel, larutan adsorbat dilewatkan pada masing-masing kolom secara bersamaan, sedangkan pada kolom seri, larutan adsorbat akan melewati kolom secara bergantian sehingga terjadi adsorpsi bertingkat. Adsorpsi dengan kolom seri dapat meningkatkan efisiensi penyisihan dan memperpanjang waktu jenuh adsorben ${ }^{[7]}$. Penelitian terdahulu membuktikan bahwa adsorpsi kolom majemuk konfigurasi seri mampu menyisihkan logam $\mathrm{Cr}^{6+}$ dan $\mathrm{Ni}^{2+}$ dengan efisiensi penyisihan berkisar 98.2-99.7\% menggunakan adsorben ampas tebu ${ }^{[9]}$ dan menyisihkan $\mathrm{Li}^{+1}$ menggunakan adsorben litium mangan oksida dengan kapasitas adsorpsi 30.7 $\mathrm{mg} / \mathrm{g}^{[10]}$.

Penggunaan adsorben dari limbah pertanian pada saat ini mendapat perhatian lebih dari para peneliti karena tersedia dalam jumlah berlimpah, murah dan mempunyai efisiensi penyisihan yang tinggi, seperti kulit kayu pinus[11], kulit jagung[12] dan sekam padi[13]. Sekam padi diketahui dapat digunakan sebagai adsorben karena memiliki kandungan selulosa, silika, lignin, karbohidrat, dan banyak mengandung gugus hidroksil dalam strukturnya ${ }^{[13]}$. Beberapa penelitian tentang pemanfaatan sekam padi sebagai adsorben untuk menyisihkan $\mathrm{Zn}$ telah dilakukan di antaranya dari air limbah laboratorium, dimana didapatkan efisiensi penyisihan mencapai $85 \%{ }^{[13]}$. Selain itu, pada adsorpsi sistem kontinu menggunakan kolom tunggal berdiameter 2.54 $\mathrm{cm}$ dan tinggi $100 \mathrm{~cm}$, sekam padi juga telah digunakan sebagai adsorben untuk penyisihan Zn dari air limbah dan diperoleh efisiensi penyisihan sebesar $96.33 \%$ dengan waktu adsorpsi 60 menit pada kecepatan alir 0.24 $\mathrm{gpm} / \mathrm{ft}^{2}$ dan ketinggian bed $70 \mathrm{~cm}^{[14]}$.

Berdasarkan uraian di atas, dalam rangka pendekatan penerapan kolom adsorpsi di lapangan dan pengolahan air tanah dalam skala yang lebih besar, pada penelitian ini dilakukan aplikasi kolom adsorpsi konfigurasi seri menggunakan adsorben sekam padi untuk menyisihkan logam $\mathrm{Zn}$ dari air tanah artifisial. Kolom yang digunakan berdiameter $7 \mathrm{~cm}$ dengan tinggi kolom $19.5 \mathrm{~cm}$ yang tersedia di pasaran dan banyak dijadikan sebagai unit pengolahan air bagi masyarakat. Hasil penelitian ini diharapkan dapat menjadi alternatif pengolahan air tanah bagi masyarakat untuk meningkatkan kualitas air tanah.

\section{Metode Penelitian}

\section{Bahan kimia}

Bahan-bahan yang digunakan dalam penelitian ini antara lain sekam padi dari sisa penggilingan padi di Kelurahan Koto Lua, Kecamatan Pauh Padang, seng klorida $\left(\mathrm{ZnCl}_{2}\right)$ (Merck, Germany), akuades dan glasswool.

\section{Peralatan}

Peralatan yang digunakan adalah kolom adsorpsi yang terbuat dari akrilik berdiameter 7 $\mathrm{cm}$ dan tinggi $19.5 \mathrm{~cm}$; wadah kolom dengan diameter atas $9 \mathrm{~cm}$, diameter bawah $8 \mathrm{~cm}$ serta tinggi $25 \mathrm{~cm}$; bak influen; wadah penampung efluen; pompa air mini/mikro DC 12V, Q = 300 $\mathrm{L} / \mathrm{h}, \mathrm{H}_{\max }=300 \mathrm{~cm}$ (ANSELF Brushless DC Pump); peralatan gelas, oven, timbangan analitik, dan Inductively Coupled Plasma (Shimadzu, ICP-9000).

\section{Prosedur penelitian}

\section{Persiapan bahan baku adsorben}

Sekam padi yang digunakan berukuran asli tanpa ada perlakuan. Sekam padi direndam dalam wadah berisi air untuk menghilangkan kotoran yang menempel, kemudian dicuci 
dengan air mengalir dan dikeringanginkan. Selanjutnya sekam padi dipanaskan dengan oven pada suhu $105{ }^{\circ} \mathrm{C}$ selama 48 menit untuk menghilangkan kandungan air yang masih tersisa. Sekam padi yang telah dipanaskan disimpan dalam wadah yang kedap udara sampai digunakan ${ }^{[15]}$.

\section{Persiapan larutan air tanah artifisial}

Larutan air tanah artifisial dibuat dengan menambahkan larutan induk logam $\mathrm{Zn}$ pada konsentrasi tertentu ke dalam air yang dijadikan sebagai pelarut. Laritan induk Zn 1000 mg/L dibuat dengan melarutkan sebanyak $4.3970 \mathrm{~g}$ bubuk seng klorida $\left(\mathrm{ZnCl}_{2}\right)$ dalam $1 \mathrm{~L}$ air. Selanjutnya larutan diencerkan untuk mendapatkan konsentrasi $\mathrm{Zn}$ yang diinginkan yaitu $7 \mathrm{mg} / \mathrm{L}$.

\section{Percobaan kolom adsorpsi}

Instalasi penelitian terdiri dari bak influen, kolom adsorpsi dan wadah penampung efluen. Bak influen dilengkapi dengan pompa untuk mengalirkan larutan ke dalam kolom. Pompa diatur dengan kecepatan alir $2 \mathrm{gpm} / \mathrm{ft}^{2}$ (310 $\mathrm{mL} /$ menit). Jumlah kolom yang digunakan 3 (tiga) buah dan dirangkai secara seri dengan aliran upflow. Adsorben diisikan ke dalam kolom pada ketinggian bed $13.5 \mathrm{~cm}$ dengan glasswool sebagai penyangga di bagian bawah dan atas kolom. Masing-masing kolom ditempatkan ke dalam wadah kolom dan disambungkan dengan pipa serta dilengkapi dengan keran efluen di setiap outlet kolomnya. Wadah penampung efluen diletakan di setiap outlet kolom. Skema instalasi penelitian dapat dilihat pada Gambar 1.

Percobaan dilakukan selama 540 menit dimulai setelah pompa pada bak influen dihidupkan dan larutan air tanah artifisial dialirkan dengan kecepatan alir $2 \mathrm{gpm} / \mathrm{ft}^{2}$ ke dalam masingmasing kolom. Sebelum running, dilakukan pengambilan sampel untuk mengetahui konsentrasi influen. Selanjutnya, waktu pengambilan sampel adalah setiap 90 menit yang dimulai dari tetesan pertama larutan keluar dari masing-masing outlet kolom. Sampel diambil dengan menampung efluen di setiap outlet kolom, kemudian dimasukan ke dalam botol dan diberi label sesuai waktu pengambilan. Selanjutnya sampel didestruksi dan diukur konsentrasi logamnya menggunakan Inductively Coupled Plasma (ICP) (Shimadzu, ICP-9000). Percobaan dilakukan secara triplo dan hasil yang didapatkan adalah rata-rata dari tiga kali percobaan.

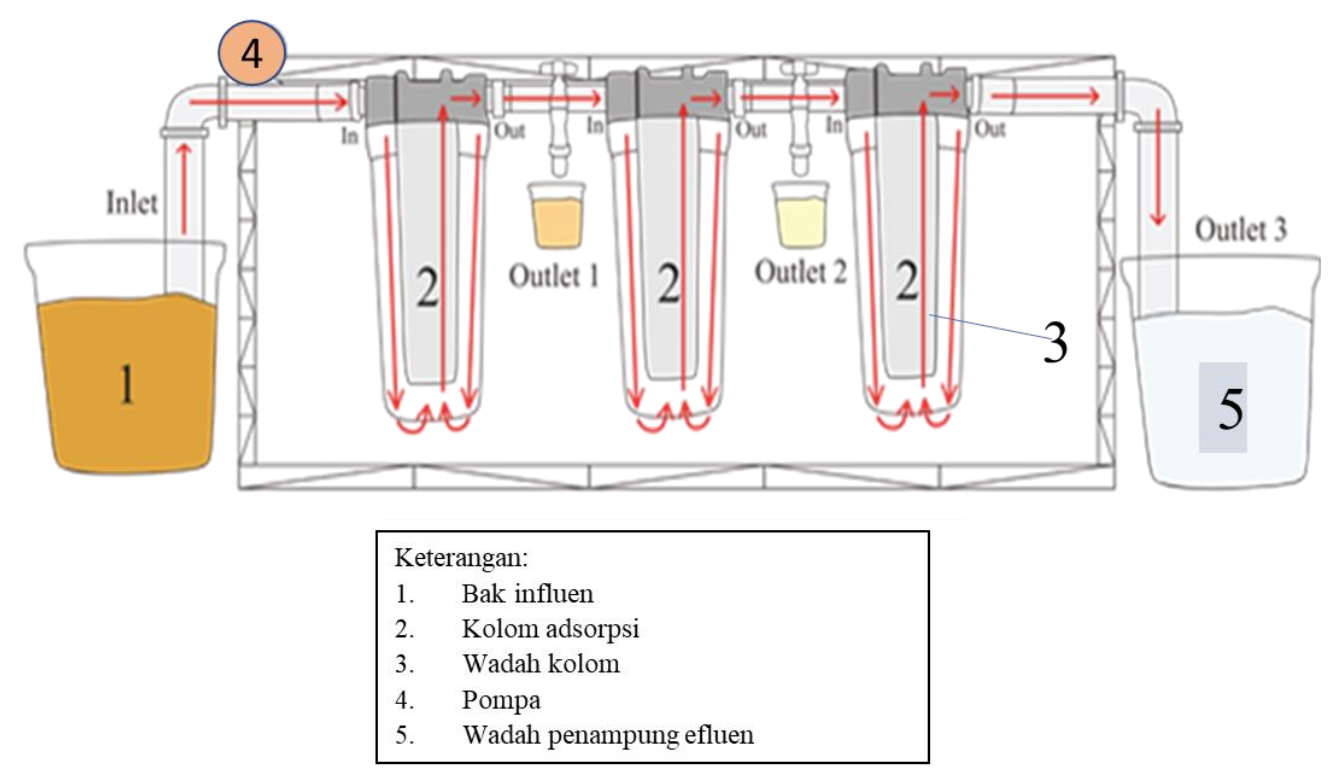

Gambar 1. Skema instalasi penelitian dan arah aliran dalam kolom. 
Kinerja kolom adsorpsi dideskripsikan dalam kurva breakthrough yang menggambarkan kondisi terjadinya peningkatan drastis jumlah adsorbat yang teradsorpsi oleh adsorben, sebelum proses adsorpsi mendekati kesetimbangan adsorpsi (Somerville, 2007). Breakthrough point ( $\mathrm{tb}_{\mathrm{b}}$ ) terjadi ketika $C_{t} / C_{0}=0.05$; sementara waktu setengah jenuh (to.5) dicapai pada saat $C_{t} / C_{0}=0.5$, dan waktu jenuh (te) terjadi saat $C_{t} / C_{0}=0.95^{[7]}$. Jumlah total konsentrasi adsorbat yang terjerap dalam kolom adsorpsi dan efisiensi penyisihan ditentukan melalui persamaan (1-5)[16].

$\mathrm{q}_{\text {total }}=\frac{\mathrm{Q}}{1000} \int_{\mathrm{t}=0}^{\mathrm{t}=\mathrm{t}_{\text {tot }}}\left(\mathrm{C}_{0}-\mathrm{C}_{\mathrm{t}}\right) \mathrm{dt}$

$\mathrm{m}_{\text {total }}=\frac{\mathrm{Q} \cdot \mathrm{C}_{0} \cdot \mathrm{t}_{\text {tot }}}{1000}$

$\mathrm{R}=\frac{\mathrm{q}_{\text {tot }}}{\mathrm{m}_{\mathrm{tot}}} \times 100 \%$

$E=\frac{C_{0}-C_{t}}{C_{0}} \times 100 \%$

$\mathrm{q}_{\mathrm{eq}}=\frac{\mathrm{q}_{\mathrm{tot}}}{\mathrm{x}}$
Dimana:

$\mathrm{q}_{\text {total }}=$ jumlah total konsentrasi adsorbat yang terjerap dalam kolom adsorpsi (mg)

$\mathrm{Q} \quad=$ laju alir influen $(\mathrm{mL} / \mathrm{min})$

$\mathrm{C}_{0}=$ konsentrasi adsorbat awal $(\mathrm{mg} / \mathrm{L})$

$\mathrm{C}_{\mathrm{t}}=$ konsentrasi adsorbat pada waktu $\mathrm{t}$ $(\mathrm{mg} / \mathrm{L})$

t total $=$ total waktu operasi kolom adsorpsi yang nilainya setara dengan waktu jenuh (menit)

$\mathrm{m}_{\text {total }}=$ massa yang melewati kolom $(\mathrm{mg})$

$\mathrm{t}=$ waktu (menit)

$\mathrm{R}=$ persentase penyisihan adsorbat $(\%)$

$\mathrm{X}=$ massa adsorben $(\mathrm{g})$

$\mathrm{E} \quad=$ efisiensi $(\%)$

$\mathrm{q}_{\mathrm{eq}} \quad=$ kapasitas adsorpsi $(\mathrm{mg} / \mathrm{g})$

\section{Hasil dan Diskusi}

\section{Penurunan konsentrasi logam $\mathbf{Z n}$}

Penurunan konsentrasi logam $\mathrm{Zn}$ pada kecepatan alir $2 \mathrm{gpm} / \mathrm{ft}^{2}$ dan ketinggian bed adsorben $13.5 \mathrm{~cm}$ dengan konsentrasi awal 7.62 $\mathrm{mg} / \mathrm{L}$ selama proses adsorpsi berlangsung dapat dilihat pada Gambar 2.

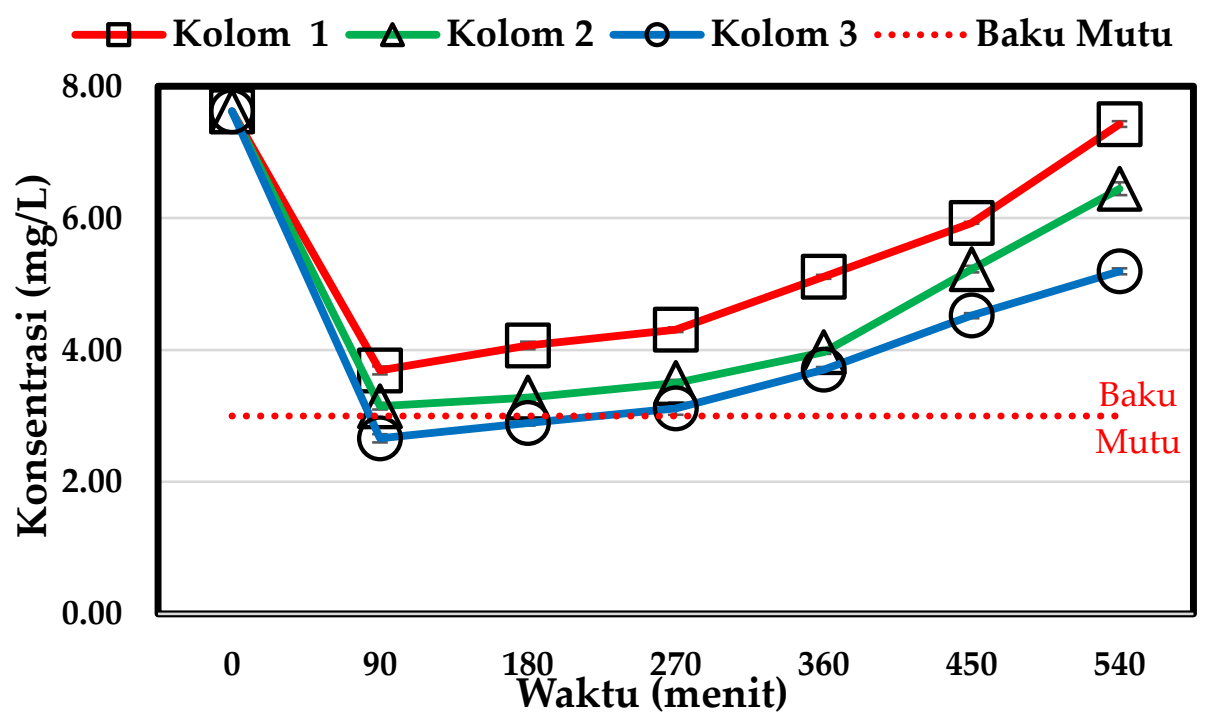

Gambar 2. Penurunan konsentrasi logam $\mathrm{Zn}$ pada masing-masing kolom selama proses adsorpsi (kecepatan alir 2 gpm/ft², ketinggian bed $13.5 \mathrm{~cm}$ dan konsentrasi awal $\mathrm{Zn} 7.62 \mathrm{mg} / \mathrm{L}$ ). 
Dari Gambar 2 terlihat bahwa pada menit ke-90 terjadi penurunan konsentrasi pada ketiga kolom. Pada menit tersebut, konsentrasi mencapai $2.662 \mathrm{mg} / \mathrm{L}$ pada kolom 3, sementara pada kolom 1 dan kolom 2, penurunan konsentrasi Zn hanya mencapai $3.707 \mathrm{mg} / \mathrm{L}$ dan $3.156 \mathrm{mg} / \mathrm{L}$. Untuk menit selanjutnya terjadi peningkatan konsentrasi hingga menit ke-540. Hal ini terjadi karena kemampuan adsorben untuk mengadsorpi semakin lama semakin menurun menuju kondisi jenuh. Sesuai dengan PERMENKES No. 492 Tahun 2010 dimana konsentrasi logam Zn yang diperbolehkan dalam air minum adalah $3 \mathrm{mg} / \mathrm{L}$, dapat disimpulkan bahwa konsentrasi logam Zn dalam efluen kolom adsorpsi dengan penggunaan 3 kolom pada menit ke-90 dan 180 telah memenuhi persyaratan baku mutu, sementara pada penggunaan 1 dan 2 kolom belum memenuhi baku mutu.

\section{Kurva breakthrough penyisihan Zn}

Kinerja adsorben sekam padi dalam menyisihkan logam Zn pada kolom adsorpsi konfigurasi seri dapat dilihat pada kurva breakthrough di Gambar 3. Gambar 3 juga membandingkan variasi penggunaan jumlah kolom, dimana didapatkan bahwa kemiringan kurva yang paling landai terdapat pada penggunaan 3 kolom dibanding penggunaan 1 dan 2 kolom. Dari Gambar 3 terlihat adsorben pada ketiga kolom telah melewati waktu breakthrough point $\left(t_{b}\right)$ pada menit ke-90 dengan rasio $C_{t} / C_{0}$ sebesar $0.484 ; 0.413$ dan 0.349 masingmasing dengan penggunaan 1, 2 dan 3 kolom. Pada menit ke-180, waktu setengah jenuh $(t 0,5)$ telah tercapai dengan penggunaan 1 kolom, sedangkan pada penggunaan 2 kolom $t_{0,5}$ tercapai pada menit ke-360 dan penggunaan 3 kolom to.5 tercapai pada menit ke- 450. Pada akhir proses yaitu menit ke-540, nilai $C_{t} / C_{0}$ pada penggunaan 1 kolom telah mencapai waktu jenuh $\left(t_{e}\right)$. Namun, penggunaan 2 dan 3 kolom belum melewati te setelah 540 menit proses adsorpsi. Dari hasil ini dapat disimpulkan bahwa penggunaan lebih dari 1 kolom dapat memperpanjang waktu untuk tercapainya waktu jenuh $\left(t_{e}\right)$ dan juga dapat memperpanjang masa pakai dari adsorben itu sendiri.

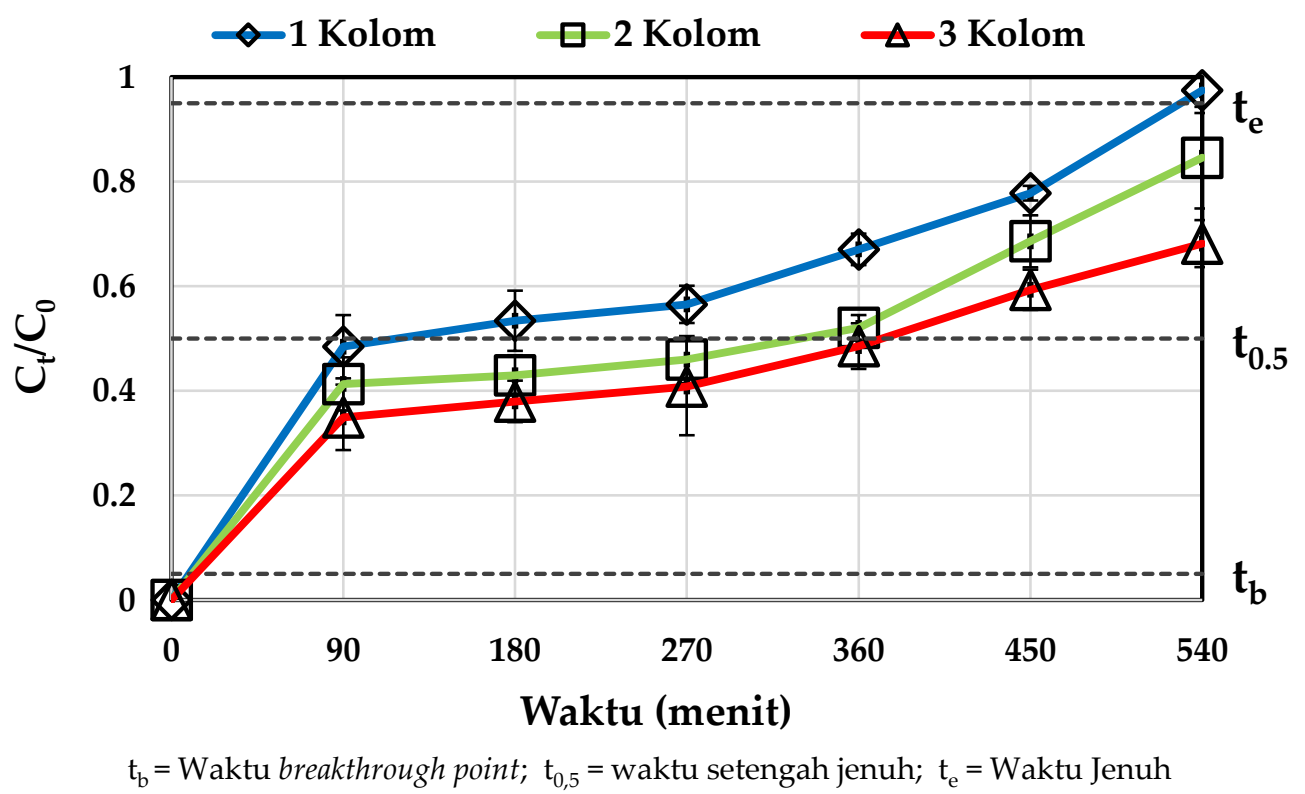

Gambar 3. Kurva breakthrough penyisihan logam Zn dari air tanah artifisial (kecepatan alir $2 \mathrm{gpm} / \mathrm{ft}^{2}$, ketinggian bed $13.5 \mathrm{~cm}$ dan konsentrasi awal Zn $7.62 \mathrm{mg} / \mathrm{L}$ ). 
Hasil ini sejalan dengan penelitian Rico et all (2014) tentang penggunaan 2 kolom adsorpsi konfigurasi seri menggunakan ampas tebu sebagai adsorben untuk menyisihkan logam $\mathrm{Cr}$ dan Ni. Pada penggunaan 2 kolom diperoleh waktu breakthrough ( $\left.t_{b}\right)$ dan waktu jenuh $\left(t_{e}\right)$ yang lebih lama dibandingkan dengan penggunaan 1 kolom. Hal ini terjadi karena pada kolom pertama telah terjadi penyisihan, sehingga konsentrasi logam yang masuk ke kolom kedua lebih rendah dibanding yang masuk ke kolom pertama $^{[9]}$.

\section{Efisiensi penyisihan dan kapasitas adsorpsi Zn}

Tabel 1 menyajikan efisiensi penyisihan dan kapasitas adsorpsi yang diperoleh dari percobaan aplikasi kolom adsorpsi konfigurasi seri. Terlihat bahwa bahwa waktu jenuh telah tercapai pada penggunaan 1 kolom, namun belum tercapai pada penggunaan 2 dan 3 kolom.
Hal ini membuktikan bahwa penggunaan lebih dari 1 kolom dapat memperlama tercapainya kondisi jenuh adsorben, sehingga memperpanjang masa pakai adsorben dalam kolom adsorpsi.

Perbandingan efisiensi penyisihan dan kapasitas adsorpsi $\mathrm{Zn}$ dapat dilihat pada Gambar 4 dan Gambar 5. Pada Gambar 4 terlihat bahwa penggunaan 3 kolom yang dirangkai secara seri menghasilkan efisiensi penyisihan lebih tinggi yaitu $51.70 \%$, diikuti oleh penggunaan 2 kolom dan 1 kolom yaitu 44.08\% dan $33.81 \%$. Hal ini sejalan dengan penelitian Rico et al, (2014) dan Ryu et al (2015) dimana didapatkan pada penggunaan lebih dari 1 kolom fixed bed menghasilkan efisiensi penyisihan yang lebih besar dibandingkan dengan penggunaan 1 kolom fixed bed[9][10].

Tabel 1. Efisiensi penyisihan dan kapasitas adsorpsi logam Zn

\begin{tabular}{cccccc}
\hline Kolom & $\begin{array}{c}\text { Efisiensi } \\
\text { penyisihan } \mathbf{( \% )}\end{array}$ & $\begin{array}{c}\text { Kapasitas adsorpsi } \\
(\mathbf{m g} / \mathbf{g})\end{array}$ & $\begin{array}{c}\text { Waktu percobaan } \\
(\mathbf{m e n i t})\end{array}$ & $C_{t} / C_{0}$ & $\begin{array}{c}\text { Kondisi } \\
\text { adsorben }\end{array}$ \\
\hline 1 & 33.21 & 6.826 & 540 & 0.975 & Telah Jenuh \\
2 & 44.08 & 4.529 & 540 & 0.846 & Belum Jenuh \\
3 & 51.70 & 3.542 & 540 & 0.682 & Belum Jenuh \\
\hline
\end{tabular}

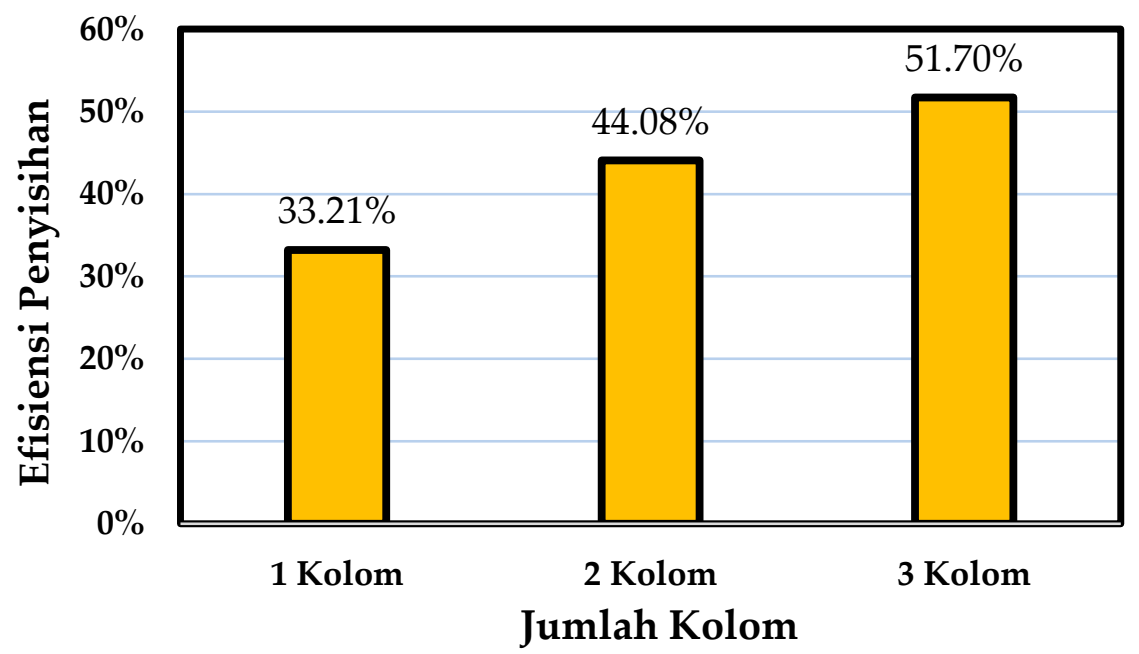

Gambar 4. Efisiensi penyisihan logam Zn pada variasi jumlah kolom konfigurasi seri (kecepatan alir 2 $\mathrm{gpm} / \mathrm{ft}^{2}$, ketinggian bed $13.5 \mathrm{~cm}$ dan konsentrasi awal $\left.\mathrm{Zn} 7.62 \mathrm{mg} / \mathrm{L}\right)$. 


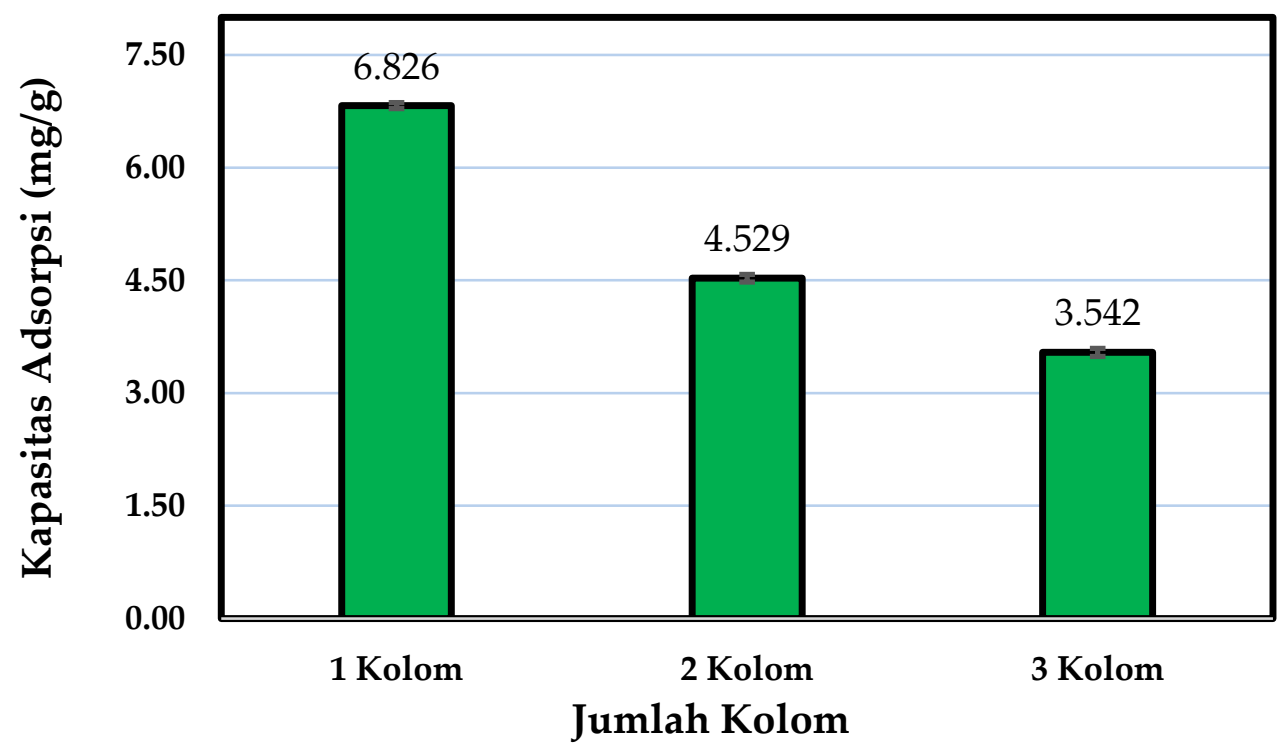

Gambar 5. Kapasitas adsorpsi logam Zn pada variasi jumlah kolom konfigurasi seri (kecepatan alir 2 $\mathrm{gpm} / \mathrm{ft}^{2}$, ketinggian bed $13.5 \mathrm{~cm}$ dan konsentrasi awal Zn $7.62 \mathrm{mg} / \mathrm{L}$ ).

Untuk kapasitas adsorpsi didapatkan hal yang berbanding terbalik, yaitu semakin banyak kolom yang digunakan maka akan semakin menurun kapasitas adsorpsi yang dihasilkan. Gambar 5 menunjukkan bahwa kapasitas adsorpsi pada penggunaan 1 kolom adalah 6.826 $\mathrm{mg} / \mathrm{g}$, sementara pada penggunaan 2 dan 3 kolom diperoleh kapasitas adsorpsi berturutturut $4.529 \mathrm{mg} / \mathrm{g}$ dan $3.542 \mathrm{mg} / \mathrm{g}$. Penurunan kapasitas adsorpsi terjadi seiring meningkatnya jumlah kolom karena jumlah atau massa adsorben juga semakin banyak. Hal ini disebabkan karena untuk perhitungan kapasitas adsorpsi, jumlah atau massa adsorben juga diakumulasikan seiring bertambahnya jumlah kolom sehingga pada penggunaan lebih dari 1 kolom menghasilkan kapasitas adsorpsi yang lebih kecil dari pada penggunaan 1 kolom saja [16].

Hal ini sesuai dengan penelitian Deng et al. (2011) tentang penyisihan logam Zn menggunakan adsorben sekam padi dengan fixed bed column berdiameter $3 \mathrm{~cm}$, tinggi $30 \mathrm{~cm}$ dan variasi kecepatan alir $0.2-0.5 \mathrm{gpm} / \mathrm{ft}^{2}$ serta variasi tinggi bed 3, 6 dan $9 \mathrm{~cm}$. Dari hasil penelitian didapatkan kapasitas adsorpsi sebesar $3.366 \mathrm{mg} / \mathrm{g}$ pada ketinggian bed yang lebih kecil yaitu $3 \mathrm{~cm}$ dibandingkan kapasitas adsorpsi pada ketinggian bed $9 \mathrm{~cm}$ yaitu sebesar $2.764 \mathrm{mg} / \mathrm{g}$. Ketinggian bed mempengaruhi massa adsorben yang digunakan untuk mengisi kolom tersebut ${ }^{[17]}$. Hal ini diperkuat dengan penelitian Barros et al. (2003) tentang penyisihan logam Cd dari air limbah pertambangan minyak dengan adsorben jamur Aspergillus niger, yang menyatakan bahwa peningkatan massa adsorben mengakibatkan terjadinya penurunan kapasitas adsorpsi dan peningkatan efisiensi penyisihan ${ }^{[18]}$.

\section{Kesimpulan}

Hasil penelitian menunjukan bahwa penggunaan lebih dari 1 kolom adsorpsi berkonfigurasi seri dapat meningkatkan efisiensi penyisihan logam $\mathrm{Zn}$ dari air tanah artifisial, dimana diperoleh efisiensi penyisihan berturut-turut $33.21 \%$, $44.08 \%$ dan $51.70 \%$ untuk penggunaan 1, 2 dan 3 kolom. Hal ini dapat terjadi karena semakin banyak jumlah kolom yang digunakan maka jumlah atau massa adsorben juga semakin banyak sehingga waktu kontak antara adsorben dengan adsorbat menjadi relatif lebih lama dan dapat meningkatkan efisiensi penyisihan. 
Peningkatan massa adsorben ini juga mengakibatkan kondisi jenuh adsorben semakin lama tercapai, sehingga proses adsorpsi dapat berlangsung lebih lama dan masa pakai adsorben menjadi lebih panjang. Hasil penelitian ini membuktikan bahwa aplikasi kolom adsorpsi seri untuk penyisihan logam Zn dari air tanah dengan adsorben sekam padi berpotensi untuk diterapkan di masyarakat.

\section{Ucapan Terima Kasih}

Ucapan terima kasih disampaikan kepada Fakultas Teknik, Universitas Andalas atas bantuan finansial untuk terlaksananya penelitian ini.

\section{Daftar Pustaka}

1. Sen, T. K. \& Gomez, D., Adsorption of zinc $\left(\mathrm{Zn}^{2+}\right)$ from aqueous solution on natural bentonite. Desalination, 267(2-3): 286-294 (2011).

2. Bhattacharya, A. K., Mandal, S. N. \& Das, S. K., Adsorption of $\mathrm{Zn}(\mathrm{II})$ from aqueous solution by using different adsorbents. Chem. Eng. J., 123(1-2): 43-51 (2006).

3. Yudo, S., Kondisi Pencemaran Logam Berat Di Perairan Sungai DKI Jakarta. J. Air Indones., 2(1): 1-15 (2018).

4. Vendini, Z. A., Studi Regenerasi Adsorben Batu Apung Sungai Pasak Pariaman yang Telah Dimodifikasi dengan Pelapisan Mg untuk Menyisihkan Logam Seng (Zn) dari Air Tanah. Universitas Andalas, (2019).

5. Widowati, Wahyu, Sationo A., Y. R., Efek Toksik Logam. Badan LitbangkesKementrian Kesehatan RI, (2008).

6. Montgomery, J. M., Water treatment: principles and design. John Wiley \& Sons, (1985).

7. Reynolds, T. \& Richard, P., Unit Operations and Processes in Environmental Engineering. PWS. Publishing Company, (1996).

8. Vaca Mier, M., López Callejas, R., Gehr, R., Jiménez Cisneros, B. E. \& Alvarez, P. J. J., Heavy metal removal with mexican clinoptilolite: Multi-component ionic exchange. Water Res., 35(2): 373-378 (2001).

9. Rodríguez Rico, I. L., Karna, N. K., Vicente, I. A., Carrazana, R. C. \& Ronda, A., Modeling of two up-flow fixed-bed columns in series for the biosorption of $\mathrm{Cr}^{6+}$ and $\mathrm{Ni}^{2+}$ by sugarcane bagasse. Desalin. Water Treat., 56(3): 792-805 (2015).

10. Ryu, T., Shin, J., Lee, D., Ryu, J., Park, I., Hong, H., Huh, Y. S., et al., Development of multi-stage column for lithium recovery from an aqueous solution. Hydrometallurgy, 157: 39-43 (2015).

11. Acemioğlu, B., Removal of Fe(II) ions from aqueous solution by Calabrian pine bark wastes. Bioresour. Technol., 93(1): 99-102 (2004).

12. Indah, S., Helard, D. \& Sasmita, A., Utilization of maize husk (Zea mays L.) as low-cost adsorbent in removal of iron from aqueous solution. Water Sci. Technol., 73(12): 2929-2935 (2016).

13. Munaf, E. \& Zein, R., The Use of Rice Husk for Removal of Toxic Metals from Waste Water. Environ. Technol., 18(3): 359-362 (1997).

14. Abbas, M. N. \& Abbas, F. S., Utilization of Iraqi Rice Husk in the Removal of Heavy Metals from Wastewater. Res. J. Environ. Earth Sci., 5(7): 370-380 (2013).

15. Asif, Z. \& Chen, Z., Removal of arsenic from drinking water using rice husk. Appl. Water Sci., 7(3): 1449-1458 (2017).

16. Zhang, W., Dong, L., Yan, H., Li, H., Jiang, Z., Kan, X., Yang, H., et al., Removal of methylene blue from aqueous solutions by straw based adsorbent in a fixed-bed column. Chem. Eng. J., 173(2): 429-436 (2011).

17. Deng, Z. F., Luo, X. G. \& Lin, X. Y., FixedBed Column Study for Zn (II) Removal from Solution Using Raw Rice Husk. Adv. Mater. Res., 197: 234-237 (2011).

18. Barros Júnior, L. M., Macedo, G. R., Duarte, M. M. L., Silva, E. P., \& Lobato, A. K. C. L., Biosorption of cadmium using the fungus Aspergillus niger. Brazilian J. Chem. Eng., 20(3): 229-239 (2003). 